\title{
Junior College Libraries Enter the Seventies
}

\begin{abstract}
The junior college as a major focus of higher education is a relatively new development in most parts of this country. An extensive questionnaire survey and program of site visits reveals norms of practice in five areas of junior college library operation: instruction in library use; community relations; collection development; staffing, hours and circulation practices; and automation. Notable trends include strong audiovisual services, liberal circulation policies, and limited professional coverage. Findings reveal a profile of library services resembling a cross between university and public library operation.
\end{abstract}

B

IG NEWS IN EDUCATION during the past decade has been the public two-year college boom. The number of junior colleges increased by over two-thirds during that time, and enrollment increased almost five-fold. In thirteen years before 1968, the proportion of all undergraduates who were in two-year colleges increased from 18 to 28 percent. By now, at least one third of all students starting higher education enter a junior college. ${ }^{1}$ Geographic distribution remains uneven; in California and Florida, over half of the undergraduates and over two-thirds of the entering freshmen are in junior colleges. ${ }^{2}$

Junior college students present a great range of traits but by and large are significantly different from four-year college students: lower in academic ability and aspirations, older, from lower socioeconomic levels. A larger proportion of them are part-time students concurrently holding a job; most are commuters.

Ms. Reeves is acting campus librarian, Cuyahoga Community College, Metropolitan Campus, Cleveland, Ohio.
In most respects they resemble their nonstudent age-peers more than they resemble four-year college students. ${ }^{3}$

Given the recent growth boom, there are many librarians who came to junior colleges with previous experience in public, school, and university libraries. They have had to adapt. Their new clients are less sophisticated than university students, yet have course-related needs which are less casual than those of most public library patrons and somewhat more challenging than those of high school students. Those in technical programs have needs that can stump the typically generalist librarian.

Most of the meager literature produced so far about junior college libraries, if not describing specific libraries, deals with standards or guidelines. This article reports instead what is actually being done at junior college libraries.

For the survey reported here, some 600 questionnaires were sent to junior college libraries in the United States; responses were received from 250 . Visits were made to 53 colleges around the country, covering the seven "pacesetter 
states" (California, Florida, Illinois, Michigan, New York, Texas, and Washington) and most of the fourteen other states which are undergoing substantial junior college development. ${ }^{4}$

The responding 250 included private as well as public colleges but private colleges were a small proportion (14 responses), partly because of the other criteria used: comprehensive curriculum (both college-parallel and technical-occupational), at least five years old, and at least 400 students. $^{5}$

In addition to basic institutional data, information was collected in five areas: (1) instruction in library use, (2) relations with the outside community, (3) collection-building, (4) staffing and public service, (5) uses of automation. (Audio-visual materials and methods, which have an important place in most junior college libraries, will be studied in a separate project.)

The sample divided itself into four approximately equal full-time-equivalent (FTE) enrollment groups, as follows: (1) under 900, (2) 900-1,999, (3) $2,000-4,299$, (4) 4,300 and over. For FTE as percent of total headcount, the median was 73 percent. As to opening year, the sample included four approximately equal groups: (1) preWorld War II, (2) 1945-1960, (3) 1961-1965, (4) 1966 and later. Nineteen percent of the respondents are located in a central city, 14 percent in an inner suburb or residential city area, and 66 percent in an outer suburb, small town, or rural area. Regular public or college-operated transportation is available to only 29 percent of the respondents. (Here's where the much-touted "open door" turns out to be partly closed.)

\section{LIBRARY INSTRUCTION}

The door is open far enough, however, to let in a great number of students who need a great deal of help in using a library. By far the most com- mon approach to library instruction, reported by 88 percent of the respondents, is group instruction to classes. English classes are the most frequent but a great variety of others were mentioned. Many librarians expressed a strong preference for giving such instruction only when it served an immediate assignment need.

Also common-reported by 73 percent -is the library manual, ranging from near-textbooks to flip-tab pamphlets. A useful variant found in a few libraries is a set of handout sheets each describing library tools for a specific subject area.

Required orientation or class visits are not very prevalent or popular. A few colleges-19 percent-offer credit courses in library use. Quite a few-40 percent -use audiovisual techniques for library instruction. Most often mentioned was a slide-tape presentation. Among the more impressive, though uncommon, techniques are: audio-tutorial programs with workbooks, a duplicate card catalog (inherited from a closed branch), and cassette-tape tours.

\section{NeIGHBORS}

Junior college libraries reflect 'reasonably well the community orientation of the parent institutions. Sixty percent of the respondents loan directly to unaffiliated community residents, some on a deposit or annual fee basis. As might be expected, the percent is somewhat higher (68 percent) among those in nearrural locations where they are often the biggest library available. Among those in central cities, only 36 percent loan to outsiders.

Wherever there is a consortium which includes academic libraries, chances are the local junior college will be represented; 44 percent reported such an affiliation. As to specific areas of cooperation with other libraries in their region, 37 percent of the respondents contribute to a union list of serials, 10 percent 
TABLE 1

\begin{tabular}{ccc}
\hline \hline FTE Enrollment & Median FTE (approx.) & Vols. per FTE Student \\
\hline $400-899$ & 650 & 35.8 \\
$900-1,999$ & 1,450 & 20.1 \\
$2,000-4,299$ & 3,150 & 12.6 \\
over 4,300 & 8,750 & 9.1 \\
\hline
\end{tabular}

to a union catalog of books, 7 percent are in a teletype system, and 8 percent reported shared acquisition or processing.

Being part of a multicampus junior college district does not seem to inspire much more sharing. Of 65 districted colleges in the sample, less than half reported any sort of district-level collaboration beyond interlibrary loan. Only 37 percent reported a union catalog of books and/or serials, and only 31 percent reported district level acquisitions, cataloging and/or processing. Campus libraries are operated autonomously in at least two-thirds of the cases; some of the others reported a district director of libraries, some reported the situation in flux, and some gave ambiguous answers. On many of my visits I sensed an edginess about campus autonomy, a reluctance to get any more involved with sister campuses than necessary-particularly in some big-city districts where the bureaucracy is inevitably heavy. The district system may be useful for raising money, increasing access, and limiting campus size in populous areas, but librarians aren't rushing in great numbers to exploit its other potentials.

\section{Collection-Building}

As can be expected, the number of volumes per FTE student is a good deal lower in junior college libraries than in academic libraries generally-an average of 19.8 volumes as compared to $51 .^{6} \mathrm{Li}$ braries with at least 70 percent of the students in college-parallel programs have a higher average, 23.4 volumes per FTE student. Enrollment makes a great deal of difference, of course. (See Table 1.)

Median FTE enrollments were identified and average volume per FTE student computed for the seven pacesetter states. Texas and Washington showed ratios somewhat lower than expected for their enrollments: Michigan and New York showed exceptionally high ratios. The private colleges averaged 42.8 per student, appropriate for their median FTE enrollment of 544. (See Table 2.)

TABLE 2

\begin{tabular}{lcc}
\hline \hline \multicolumn{1}{c}{ State } & Median FTE & Vols. per FTE Student \\
\hline California & 5,535 & 10.2 \\
New York & 3,808 & 15. \\
Illinois & 3,312 & 12.7 \\
Florida & 2,383 & 18.1 \\
Washington & 2,316 & 14.2 \\
Michigan & 2,287 & 19.7 \\
Texas & 1,135 & 20.3 \\
\hline
\end{tabular}

Annual growth rate of book collections varies somewhat with age. The median rate is about 10 percent. For colleges and universities generally, the average is 7.7; their median age is of course a lot higher. ${ }^{7}$ For schools in the youngest age group, 5 years old or less, the median growth rate is about 15.5 percent. In the next age group it is about 10.5 percent, in the $1941-60$ age group it is about 9 percent, and in the oldest group it is about 8 percent. In each age group there are some schools in each growth rate quartile; the youngest age group shows the least amount of spread. New York and Illinois schools show growth rates a bit higher than the norm for their median age group; 
Michigan schools are a bit behind in that respect.

Participation of teaching faculty in book selection varies widely; the proportion of books selected by them averages 46 percent. Measures to encourage faculty involvement, such as circulation of CHOICE cards and publishers' literature, active library committees, specific liaison assignments for librarians and/ or teachers, and frequent reporting, generally seems to pay off. Many librarians find it necessary to cull faculty requests which are too numerous or too high-level. Intangible factors such as personal relationships and general faculty morale have impact here; a high faculty turnover rate seems to hamper faculty-library cooperation.

Departmental book budgets are rare for junior college libraries, reported by only 19 percent; some others allocate informally within the library budget. Slightly over half of the respondents reported 1 percent or more of their books to be student-selected. Less than 10 percent reported routine purchase of currently used textbooks. Very few use approval plans, except for reviewing films. One percent of the collection or less is kept on Reserve by 41 percent of the sample; 14 percent reported keeping over 3 percent on Reserve. A few of the respondents are government document depositories, most but not all of them in near-rural locations. A good many libraries provide popular reading via the McNaughton plan and/or a paperback collection.

In use of book-selection tools, junior college librarians appear to have one foot in each camp, i.e. public and academic libraries. CHOICE was the most frequently mentioned as a tool in regular use ( 85 percent). Next came Library Journal (66 percent), Booklist (41 percent) and The New York Times Book Review (33 percent). Other sources mentioned by over 10 percent of the respondents were Publishers' Weekly, pub- lishers' literature, specialized journals, Wilson Library Bulletin, Saturday Review, and Books for Junior College Libraries. (Tools such as BJCL would no doubt have been more prominent had the sample included the youngest libraries.)

Almost all of the respondents (95 percent) reported the use of jobbers. Some use them for only a small proportion of their purchases, but most use them for the bulk of their purchases (average, 70 percent). In some cases the cataloging and processing are also handled by the jobber. Even among colleges using shared acquisition services, well over half reported using jobbers for 60 percent or more of their purchases.

\section{Staffing and Service}

Most junior college libraries manage to have a professional on duty during all open hours. As a group, however, they lag behind other academic libraries in ratio of professional staff to students. Academic libraries as a whole average one to 410 ; junior college libraries average one to $658 . .^{8}$ If we assume the use of jobbers to be more common in junior colleges, that provides some explanation. Of course junior college libraries also don't need bibliographers, archivists, or subject specialists, as university libraries do. Junior college libraries, on the other hand, are more likely to need media specialists on their staffs. And their students have more need for individual professional help; you can't just point to the catalog and hand them a map.

Again, of course, the ratio varies with school size. The private colleges' ratio of one to 301 fits their median enrollment of 544. (See Table 3.)

Among the pacesetter states, New York, Illinois, and Florida showed relatively favorable ratios with respect to their enrollments; Washington, California, and Michigan were behind the 
TABLE 3

\begin{tabular}{ccr}
\hline \hline FTE Enrollment & $\begin{array}{c}\text { Median FTE } \\
\text { (Approx.) }\end{array}$ & Student: Prostaff \\
\hline $400-899$ & 650 & $352: 1$ \\
$900-1,999$ & 1,450 & $519: 1$ \\
$2,000-4,299$ & 3,150 & $711: 1$ \\
4,300 and over & 8,750 & $1,088: 1$ \\
\hline
\end{tabular}

TABLE 4

\begin{tabular}{lcc}
\hline \hline State & Median FTE & Student: Prostaff \\
\hline California & 5,535 & $1,312: 1$ \\
New York & 3,808 & $552: 1$ \\
Illinois & 3,312 & $680: 1$ \\
Florida & 2,383 & $507: 1$ \\
Washington & 2,316 & $834: 1$ \\
Michigan & 2,287 & $728: 1$ \\
Texas & 1,135 & $451: 1$ \\
\hline
\end{tabular}

norm for their enrollments. (See Table 4.)

Almost all the libraries (239) reported employing at least one library professional; on the average they comprise 40 percent of the staff. Thirty-nine percent of the professional librarians have a second master's degree. The professional librarians generally have faculty status.

Almost half reported a nonlibrary professional on the staff; where present, such comprised on the average 22 percent of the staff. This amounts to an overall average of roughly 10 percent; for academic libraries as a whole the figure is 5 percent. $^{9}$ The most common role is that of audiovisual specialist, reported by about 43 percent of the respondents employing a nonlibrary professional. (This position is filled by a library professional in 16 percent of the libraries.) Circulation and technical service roles for nonlibrary professionals were each reported by 12 percent of the respondents who employ them.

In colleges which educate paraprofessionals and which do not operate at the highest academic level, one might expect to find library paraprofessionals and indeed 45 percent of the respondents re- port employing them. ${ }^{10}$ Where employed, the LTA averages 23 percent of the staff. Use of LTA's probably explains in part the poor professional-tostudent ratio. LTA's are often put in charge of circulation or periodicals, positions more likely to be held by professionals in university libraries. Only 17 percent of the junior colleges reported a professional librarian in charge of circulation and only 14 percent reported one in charge of periodicals.

Where LTA's are employed by junior college libraries they have a higher salary level than clerical staff in 80 percent of the cases. As we know, however, acceptance of the LTA varies with locality and librarian. Almost 40 percent of the libraries whose institutions train LTA's do not hire them. The State University of New York provides no LTA salary level, but New York civil service does so de facto with its middle level of "Principal Library Clerk." Illinois civil service doesn't even have a de facto salary level for library paraprofessionals. California civil service provides a slot for LTA's, and many California junior college libraries hire them. Probably the best climate for LTA's is in North Carolina: several junior colleges train them, most hire them, and the civil service recognizes them.

Economic climate can play havoc with the LTA's status. Where the unemployment rate is high, most librarians seem quite willing to under-employ and will hire college, sometimes even library science, graduates into LTA positions. The same situation may occur in university communities where there are collegeeducated "captive wives."11

Audiovisual paraprofessionals, or media technicians, are employed by about 41 percent of the respondents, and where present, account for 14 percent of the staff on the average. Library clerks are almost as sure to be found (88 percent) as professional librarians, and average 44 percent of the staff. All 
of the libraries hire student assistants.

From the data there emerges a profile of a prototype junior college library staff serving an FTE enrollment of 2,250 . It looks like this: three professional librarians, one with a second master's; one nonlibrary professional for AV services or one library paraprofessional; three library clerks; and one half-time media technician.

The newer junior college libraries generally use microfilm rather than bind back periodicals, or buy microfilm for some and keep others loose for a few years. Many older libraries continue or complement their bound collection with microfilm. Almost one-third of the libraries circulate their unbound periodicals. Some libraries circulate practically anything mobile-not only phonodiscs but cassette tapes and players, art prints, microfiche and readers, even reference books.

Among valuable fringe services common in junior college libraries are typewriters (coin-op or free), photocopy machines, and conference rooms. Some libraries provide calculators in the typing rooms. Some will transfer library audio holdings to a student's own tape. At one, I found a few drafting tables.

Almost all of the libraries are open weekday evenings except Friday. Thirtyfive percent report Saturday open hours and 35 percent report Sunday hours, some having both; altogether, 53 percent are open some time on the weekend. Saturday classes are reported for over half of the schools that have Saturday library hours; Sunday classes are very rare. Sunday hours appear to get much more student use than do Saturday hours. Weekend hours are slightly less common than average for central city schools. They are no more common with the 23 percent which have residential facilities except for the private schools; 13 of the 14 private colleges have dormitories and 12 of them have weekend library hours.
There was no formal effort to determine the prevalent classification system used, but interview notes and manuals for part of the sample indicate that roughly two-thirds are using LC. Many of these have switched over from Dewey during the past decade or so; one California librarian observed that the rush to LC seems over now, and many West Coast libraries remain "unconverted." Most of the Washington junior colleges use Dewey. Those in New York's SUNY and CUNY system and in the Chicago system use LC. When asked, most librarians seemed happy with whichever system they have. Those using LC consider it more economical (one library reduced the number of catalogers from $2 \frac{1}{2}$ to one after the switch). Those using Dewey consider it more suitable for their students and their collection.

\section{Automation}

Only 27 percent of the respondents have automated one or more of their operations. Half of those are in the largest enrollment group, and the use of automation decreases as school size decreases. Automation was reported most frequently for catalog production (14 in card form, 13 in book form, and two on microfilm). Other areas of automation, in descending order of frequency, are circulation, serials list (sometimes with check-in control), shelflist, acquisitions, various specialized lists, and pocket/label production. In almost half the cases, keypunching or tape-typewriting is done by library staff; in 23 percent of the cases at least some of the programming is done by library staff. Further automation is planned for 53 percent of those reporting automated operations.

\section{Where We Stand}

In reporting library operating expenditure as a percentage of total college expenditure, the respondents pro- 
duced an average percent of 5.1 percent. For all academic libraries this percent was reported to be 3.8 for the same year $(1970-71)$ in The Bowker Annual and 4.3 for 1968-69 in the HEW Analytic Report. (See Table 5.)

TABLE 5

\begin{tabular}{lc}
\hline \hline State & $\begin{array}{c}\text { Library Expenditure as Percent of } \\
\text { Total Institutional Expenditure }\end{array}$ \\
\hline Washington & $5.9 \%$ \\
Florida & 5.8 \\
Texas & 5.5 \\
Illinois & 5.2 \\
Michigan & 5.2 \\
New York & 3.8 \\
California & 3.6 \\
\hline
\end{tabular}

Two plausible reasons come to mind for the higher percent in junior colleges. One is that a large proportion of them are in their early years when relatively high book budgets are necessary. The other reason is the greater prominence of audiovisual media in junior college libraries.

Although the questionnaire did not cover AV services directly, it is evident from staffing data, unsolicited written comments, and visit notes that at least half of the libraries handle most of their colleges' AV activities. For those that do so, the average percent of total college expenditues is 5.3 and the average expense per volume acquired is $\$ 10.06 .^{12}$

For the other libraries, the averages are 5 percent and \$7.95. An indication that junior college libraries exceed academic libraries generally in audiovisual services is the fact that roughly 10 percent of the academic library "book" budgets are spent on audiovisual materials, whereas in one of the pacesetter states 29 percent of all junior college library materials are nonprint. ${ }^{13}$

As junior college libraries enter the seventies, several observations based on my visits seem relevant. Most libraries provide a variety of audiovisual materials. Many are not as service-oriented as they should be: they tend to be short on professional staff and it was rare to find a staff that seemed always ready to take the initiative with a student who had a "question on his face."

Many of the libraries that I saw were recently-built. Most seemed attractive, easy to run and easy to use, some were noisy or badly cut up, or had such burdens as two major entrance-exit areas. Many of the host/hostess librarians whom I visited were not only cordial and helpful but seemed energetic, creative, and effective. I was especially impressed with the librarians I encountered in the Northwest. Among other libraries on my itinerary that seemed especially successful were: Macomb-South (Michigan), Monroe (New York), St. Petersburg-Clearwater (Florida), Wilkes (North Carolina), Florissant Valley (Missouri), and San Antonio (Texas).

\section{VISITS}

Monroe County Community College, Monroe, Michigan

Macomb County Community College, South Campus, Warren, Michigan

Oakland Community College, Orchard Ridge Campus, Farmington, Michigan

Schoolcraft College, Livonia, Michigan

Erie Community College, North Campus, Buffalo, New York

Monroe Community College, Rochester, New York

Malcolm X College, Chicago, Illinois

Wilbur Wright College, Chicago, Illinois

College of DuPage, Glen Ellyn, Illinois

Joliet Junior College, Illinois

Lakeland Community College, Mentor, Ohio

Lorain Community College, Lorain, Ohio

Sinclair Community College, Dayton, Ohio

Community College of Allegheny County, Pittsburgh, Pennsylvania 
Worcester Junior College, Massachusetts (Independent)

Holyoke Community College, Massachusetts

Bronx Community College, New York

Borough of Manhattan Community College, New York

New York City Community College, Brooklyn, New York

Northampton County Area Community College, Bethlehem, Pennsylvania

Community College of Philadelphia, Pennsylvania

Montgomery College, Rockville, Maryland

St. Petersburg Junior College, St. Petersburg, Florida

St. Petersburg Junior College, Clearwater, Florida

Miami-Dade Junior College, South Campus, Florida

Miami-Dade Junior College, North Campus, Florida

Palmer College, Charleston, South Carolina (Independent)

Kennesaw Junior College, Marietta, Georgia

Clayton Junior College, Forest Park, Georgia

Caldwell Community College \& Technical Institute, Lenoir, North Carolina

Wilkes Community College, Wilkesboro, North Carolina

Florissant Valley Community College (St. Louis District), Ferguson, Missouri

Meramec Community College (St. Louis District), Kirkwood, Missouri
Penn Valley Community College, Kansas City, Missouri

Navarro Junior College, Corsicana, Texas

El Centro College, Dallas, Texas

Tarrant County Junior College, South Campus, Fort Worth, Texas

San Antonio College, San Antonio, Texas

Phoenix College (Maricopa Co. J. C. District), Phoenix, Arizona

Golden West College, Huntington Beach, California

Fullerton Junior College, Fullerton, California

Riverside City College, Riverside, California

Citrus College, Azusa, California

Allan Hancock College, Santa Maria, California

College of San Mateo, San Mateo, California

Laney College (Peralta District), Oakland, California

San Jose City College, California

DeAnza College, Cupertino, California

Lane Community College, Eugene, Oregon

Clackamas Community College, Oregon City, Oregon

Skagit Valley College, Mount Vernon, Washington

Shorline Community College, Seattle, Washington

Green River Community College, Auburn, Washington

REFERENCES

1. We won't get hung up on terminology. "Junior" and "community" college are equally common terms; "junior" is shorter.

2. Leland L. Medsker and Dale Tillery, Breaking the Access Barriers: A Profile of Two-Year Colleges (McGraw-Hill, 1971), Ch. 2.

3. Ibid., Ch. 3 .

4. So identified by Medsker \& Tillery, p. 22.

5. Because I selected from Junior College Di- rectory, which gives founding dates rather than opening dates, I included many that are less than five years old; several responded and were counted.

6. Bronson Price \& Doris C. Holladay, Library Statistics for Colleges and Universities, Fall 1969 Analytic Report (U.S. Dept. of H.E.W., 1971), p. 24 (reporting for 1968$69)$. The average for public institutions was 37 . 
7. The Bowker Annual of Library and Book Trade Information, 1970-71, p. 8-10.

8. Ibid., In computing the ratio of professional staff to students, I included nonlibrary professionals, defined as people with a college or university degree in a field other than librarianship. If, as seems evident, the Bowker ratio of 1 to 410 excludes nonlibrary professionals, then the junior college ratio is even less favorable by comparison.

9. Price \& Holladay, LSCU Fall 1969 Analytic Report, p. 2.

10. For this survey they were called "Library Technical Assistant" and were defined as graduates of a two-year college Library Technology program or employees having at least one year of college plus library work experience.
11. The questionnaire defined the minimum qualifications for LTA's but did not ask about the backgrounds of those on the staff. Interview discussions revealed that many people classed as LTA's actually had professional qualifications.

12. I asked for the number of (book) volumes added during the past year, and for the "expenditure for books, including nonbook reading and study materials," for the same year.

13. Bowker Annual, p. 55; Washington State Assn. of Community College Librarians and Media Specialists, A Survey of the Learning Resources Programs in the Community Colleges of Washington State, 1970. Library News Bulletin 37:300-301 (Oct.Dec. 1970). 